\title{
Estrogen can signal through multiple pathways to regulate oocyte cyst breakdown and primordial follicle assembly in the neonatal mouse ovary
}

\author{
Ying Chen, Kelsey Breen and Melissa E Pepling \\ Department of Biology, Syracuse University, 107 College Place, Syracuse, New York 13244, USA \\ (Correspondence should be addressed to M E Pepling; Email: mepeplin@syr.edu)
}

\begin{abstract}
During mouse embryonic development, oocytes develop in germline cysts, formed by several rounds of cell division followed by incomplete cytokinesis. Shortly after birth, cysts break down and individual oocytes are enclosed by granulosa cells to form primordial follicles. At the same time, two-thirds of the oocytes die by apoptosis with only one-third surviving. We have previously shown that the steroid hormones, estradiol $\left(\mathrm{E}_{2}\right)$, and progesterone as well as the phytoestrogen genistein can inhibit cyst breakdown and primordial follicle assembly. However, the mechanisms by which steroid hormones regulate oocyte cyst breakdown and selective oocyte survival are unknown. Here, we confirmed the expression of estrogen receptor (ER) mRNA and protein in neonatal mouse ovaries using reverse transcriptase-PCR, western blotting, and immunocytochemistry. We then used ER-specific agonists and antagonists to understand the mechanism of estrogen signaling. $\quad 4,4^{\prime}, 4^{\prime \prime}$-(4-propyl-[1H]-pyrazole-1,3,5-triyl)
\end{abstract}

trisphenol, an ER $\alpha$-selective agonist, and 2,3-bis (4-hydroxyphenyl)-propionitrile, an ER $\beta$-selective agonist, both inhibited cyst breakdown in organ culture, suggesting that $\mathrm{E}_{2}$ can signal through both the receptors to regulate cyst breakdown. ICI 182,780, an ER antagonist, completely blocked $E_{2}$ 's action. 1,3-bis(4-hydroxyphenyl)-4-methyl-5[4-(2-piperidinylethoxy)phenol]-1H-pyrazole dihydrochloride, an ER $\alpha$-specific antagonist, fully blocked $E_{2}$ 's effect on oocyte cyst breakdown and primordial follicle assembly and (R,R)-5,11-diethyl-5,6,11,12-tetrahydro-2,8chrysenediol, an ER $\beta$-specific antagonist, partially blocked $\mathrm{E}_{2}$, further supporting the idea that both receptors are involved in estrogen signaling in neonatal oocyte development. $E_{2}$ conjugated to BSA, which can only exert effects at the membrane, was able to inhibit cyst breakdown, implying that $\mathrm{E}_{2}$ could also function through a membranebound ER to regulate cyst breakdown.

Journal of Endocrinology (2009) 202, 407-417

\section{Introduction}

Formation of functional gametes is essential for reproduction. In the mouse, primordial germ cells (PGCs) migrate to the gonad during embryonic development (Bendel-Stenzel et al. 1998). In the female, after the PGCs arrive at the gonad, they proliferate until 13.5 days post coitum (dpc) when they initiate meiosis (Pepling 2006). During this time, cysts are formed because each round of mitosis is followed by incomplete cytokinesis leaving the oogonia connected by intercellular bridges (Pepling \& Spradling 1998). Shortly after birth, the cysts undergo breakdown, accompanied by apoptosis of about two-thirds of the germ cells (Pepling \& Spradling 2001). Then, each individual germ cell associates with somatic (granulosa) cells and becomes enclosed in a primordial follicle. Apoptosis is thought to be the primary mechanism by which the multicellular cysts break apart into single oocytes (Pepling \& Spradling 2001, Greenfeld et al. 2007). However, it is unknown how cyst breakdown is regulated or coordinated with neonatal development.
Recent research has implicated estrogen signaling in the cyst breakdown process. Neonatal exposure to genistein, an estrogen-like compound from soy, induces multiple oocyte follicles (MOFs) in the mature mouse ovary (Jefferson et al. 2002). During neonatal ovary development, genistein-treated mice had significantly more oocytes still in cysts compared with control mice (Jefferson et al. 2006). These results support the idea that MOFs observed in the genistein-treated adult ovaries result from incomplete breakdown of oocyte cysts during neonatal oocyte development. In our previous work, we have found that estradiol $\left(\mathrm{E}_{2}\right)$ inhibited cyst breakdown and primordial follicle assembly both in vitro and in vivo (Chen et al. 2007).

Estrogens function via nuclear receptors, which are members of the steroid hormone receptor superfamily. There are at least two estrogen receptors (ERs) in mammals namely ER $\alpha$ and $E R \beta$ (Pettersson \& Gustafsson 2001) that are also listed as ESR1 and ESR2 in the MGI Database. In addition to acting as nuclear hormone receptors, there is evidence that ERs can be translocated to and act at the plasma 
membrane (Pedram et al. 2006). Recent studies have also provided evidence that estrogen may also signal through membrane-bound receptors including a G-coupled membrane receptor called GPR30 (Revankar et al. 2005). Like normal wild-type mice, Er $\alpha$-deficient mice treated with genistein also have MOFs. However, $\operatorname{Er} \beta$ knockout mice treated with genistein do not have MOFs, implying that $\operatorname{Er} \beta$ is the major ER in the breakdown process (Jefferson et al. 2002).

The importance of estrogen signaling in female fertility has been investigated in ER knockout mice. Er $\alpha$ knockout females are infertile, do not ovulate, and lack corpora lutea (Lubahn et al. 1993, Dupont et al. 2000). Instead, there are a high number of abnormal hemorrhagic or atretic antral follicles. $\operatorname{Er} \beta$ knockout female mice are subfertile with fewer and smaller litters (Krege et al. 1998). In contrast to Er $\alpha$ knockout mice, $\operatorname{Er} \beta$ knockout mice have some corpora lutea although fewer than wild-type. Loss of both receptors in the double knockout mice leads to female infertility and ovaries that lack corpora lutea similar to ER $\alpha$ mutants. However, in contrast to Er $\alpha$ knockouts, the double mutants have Sertolilike cells arranged into structures resembling seminiferous tubules, suggesting that the two ERs are required for the maintenance of ovarian cell identity (Couse et al. 1999). It is not known whether mutation of either or both ERs affects the process of cyst breakdown.

ERs are expressed in a variety of tissues. Both receptors are expressed in the adult ovary (Enmark \& Gustafsson 1999). $\mathrm{ER} \alpha$ protein is localized primarily in the theca cells in adult mice (Enmark \& Gustafsson 1999), while in fetal ovaries, it is localized to a few stromal cells and the epithelium (Nielsen et al. 2000). ER $\beta$ is expressed in the granulosa cells starting from postnatal day (PND) 5 (Jefferson et al. 2000). Although ER $\beta$ RNA has been detected earlier at PND 1 by reverse transcriptase (RT)-PCR, it is unknown whether ER $\beta$ protein is present in the neonatal ovaries, and if so what cell type it is localized to.

In this study, we examined the expression of ERs in the neonatal mouse ovary using RT-PCR, western-blot analysis, and immunocytochemistry. Both ER mRNAs are present in the neonatal ovary, suggesting that estrogen could signal through either receptor to regulate cyst breakdown and primordial follicle formation. We then utilized ER-specific agonists and antagonists to determine the role of each ER. We found that both ER-specific agonists inhibit cyst breakdown, while receptor-specific antagonists block the effects of estrogen in the ovary. We also provide evidence supporting the role of a membrane ER (mER) in neonatal oocyte development.

\section{Materials and Methods}

\section{Animals}

Adult cluster of differentiation-1 female mice were obtained from Charles River Laboratories (Wilmington, MA, USA) and bred to male mice of the same strain. Vaginal plug detection was considered to be day 0.5 of pregnancy. Pregnant mice delivered pups at $19.5 \mathrm{dpc}$, which were designated PND 1. Pregnant mice were housed under controlled lighting (12 h light: $12 \mathrm{~h}$ darkness cycles) and temperature $\left(21-22{ }^{\circ} \mathrm{C}\right)$ conditions. All animal procedures complied with the Syracuse University Institutional Animal Care and Use Committee.

\section{In vitro ovary organ culture}

Ovaries were collected at PND 1 and placed into culture for 7 days. Ovaries were cultured in drops of media on $0.4 \mu \mathrm{M}$ floating filters (Millicell-CM, Millipore Corp., Bedford, MA, USA) in $0.4 \mathrm{ml}$ DMEM-Ham's F-12 media supplemented with penicillin-streptomycin, $5 \times$ ITS-X (Life Technologies, Inc.), $0 \cdot 1 \% \mathrm{BSA}, 0 \cdot 1 \%$ albumax, and $0.05 \mathrm{mg} / \mathrm{ml} \mathrm{L}$-ascorbic acid in four-well culture plates. Ovaries were grown in culture medium alone or in the presence of estrogen agonists or antagonists as noted, which was added daily. The ovaries were randomly distributed to different treatment groups. The data for control ovaries for the E2-BSA studies were collected in a separate experiment.

Chemicals used in the in vitro studies were as follows: ( $\mathrm{E}_{2}$, Sigma Chemical Company); 4,4 $4^{\prime \prime}$-(4-propyl-[1H]pyrazole-1,3,5-triyl)trisphenol (PPT, Tocris Cookson Inc., Ellisville, MO, USA); 2,3-bis(4-hydroxyphenyl)-propionitrile (DPN, Tocris Cookson Inc.); 1,3-bis(4-hydroxyphenyl)4-methyl-5-[4-(2-piperidinylethoxy)phenol]-1H-pyrazole dihydrochloride (MPP, Tocris Cookson Inc.); (R,R)-5, 11-diethyl-5,6,11,12-tetrahydro-2,8-chrysenediol ( $(\mathrm{R}, \mathrm{R})$ THC, Tocris Cookson Inc.); $7 \alpha, 17 \beta-[9[(4,4,5,5,5$-pentafluoropentyl)sulfinyl]nonyl]estra-1,3,5(10)-triene-3,17-diol (ICI 182,780, Tocris Cookson Inc.); albumin-FITC conjugate (BSA-FITC, Sigma-Aldrich Inc.); and $\beta-\mathrm{E}_{2}$ 6-(O-carboxy-methyl)oxime: BSA-FITC conjugate (E $\mathrm{E}_{2}-\mathrm{BSA}-\mathrm{FITC}$, Sigma-Aldrich Inc). All chemicals were dissolved in DMSO at a concentration of $0 \cdot 1 \mathrm{M}$ and then added to culture media to achieve the desired final concentration. DMSO was added to media at the same percent as compound treatment $(<0 \cdot 1 \%)$ to serve as a vehicle control. All chemicals were added at the start of organ culture except for antagonist studies using MPP, R, R-THC, and ICI 182,780 where the antagonist was added first and $\mathrm{E}_{2}$ was added $6 \mathrm{~h}$ later.

\section{Whole-mount immunohistochemistry and fluorescence microscopy}

Ovaries collected after in vitro experiments or for ER localization studies were fixed in 5\% electron microscopy grade paraformaldehyde (Ted Pella, Inc., Redding, CA, USA) in PBS overnight at $4{ }^{\circ} \mathrm{C}$ followed by several washes in $0 \cdot 1 \%$ Triton X-100 in PBS and then incubated with 5\% BSA in $0 \cdot 1 \%$ Triton X-100 in PBS to block nonspecific binding. Whole ovaries were immunostained as previously described (Murphy et al. 2005). The STAT3 (C20) antibody (Santa Cruz Biotechnology, La Jolla, CA, USA) was used at 
a dilution of 1:500 (Murphy et al. 2005). The secondary antibody anti-rabbit Alexa 488 (Molecular Probes, now part of Invitrogen) was used at a dilution of 1:200. Propidium iodide (Molecular Probes, now part of Invitrogen) was used to label nuclei. Samples were imaged on a Zeiss Pascal Confocal microscope (Carl Zeiss MicroImaging, Inc., Thornwood, NY, USA). For analysis of ER expression in neonatal cluster of differentiation-1 ovaries, tissues were treated as above except the primary antibodies used were $\mathrm{ER} \alpha(\mathrm{MC} 20)$ at 1:100 (Santa Cruz Biotechnology) and ER $\beta$ (311) at 1:250 (Affinity Bioreagents, Golden, CO, USA).

Analysis of oocyte cyst breakdown, primordial follicle assembly, and follicle development

Whole ovaries were labeled with an antibody against STAT3, a specific marker for germ cells. Ovaries were examined for percent single oocytes relative to the total number of oocytes to assess oocyte cyst breakdown (Jefferson et al. 2006). The number of individual oocytes relative to the number of oocytes in cysts was determined by examining eight optical regions per ovary. These regions were obtained by examining two areas of the ovary and taking four representative, confocal sections at least $20 \mu \mathrm{m}$ apart in each area. For each region, a single confocal section was examined. In addition, for each of these regions, a stack of 10 sections, $1 \mu \mathrm{m}$ apart centered around the single confocal section, was obtained. This stack of sections was used to determine whether oocytes in the center section were associated with oocyte nests above or below the plane of focus. For each oocyte in the single section that appeared not to be associated with other oocytes, sections above and below were examined to confirm that the oocyte was not in a cyst. For primordial follicle assembly and development, the number of each type of follicle per region was determined. For primordial follicle assembly, oocytes were considered unassembled if granulosa cells did not completely surround them or if STAT3 antibody labeling showed that the oocytes were associated. Follicles were classified as follows: primordial (oocyte surrounded by several flattened granulosa cells), primary (oocyte surrounded by one layer of cuboidal granulosa cells), or secondary (oocyte surrounded by at least two layers of granulosa cells).

\section{Determination of germ cell number}

The number of oocytes per section was determined by counting the number of oocytes in the eight representative, confocal sections that were collected for analysis of cyst breakdown and determining the average number of oocytes per section.

\section{Statistical analysis}

One-way ANOVA was conducted to look at treatment effects on oocyte number, percent single oocytes, follicle assembly, and follicle development. PROC GLM of SAS 9.1
(SAS Institute Inc., Cary, NC, USA) was used to calculate the least-squares means and test-specific hypotheses for effects. $P$ value $<0 \cdot 05$ was considered significant.

\section{$R N A$ isolation from mouse ovaries}

Ovaries were dissected in PBS and kept on ice. Twenty microliters of Trizol (Invitrogen) per ovary were added and ovaries were then homogenized by hand. The homogenates were pooled until 40 ovaries were collected. The homogenate was phase separated with $20 \mu \mathrm{l}$ of $1 \mathrm{mg} / \mathrm{ml}$ glycogen and $160 \mu \mathrm{l}$ of chloroform. The mixture was centrifuged at $15000 \mathrm{~g}$. for $15 \mathrm{~min}$ at $4{ }^{\circ} \mathrm{C}$ and the top phase was kept. The RNA was washed with $400 \mu \mathrm{l}$ of isopropanol and then with $70 \%$ ethanol. The RNA pellet was air dried and dissolved in $25 \mu \mathrm{l}$ of PCR grade water. It was incubated at $55^{\circ} \mathrm{C}$ for $10 \mathrm{~min}$ and then stored at $-80^{\circ} \mathrm{C}$ until further use.

\section{Reverse transcriptase PCR}

RT (Invitrogen) was used to create cDNA, primed with a poly $(\mathrm{T})$-containing primer $\left(3^{\prime}\right.$ race primer (Invitrogen)), from Trizol-extracted RNA. The mixture of cDNA thus produced, representing mRNA, was then subjected to PCR or nested PCR using primers specific to the gene of interest. Specifically for $\operatorname{ER} \alpha$ and $\operatorname{ER} \beta, \mathrm{cDNA}$ was subjected to the first round of PCR for 20 cycles: $94^{\circ} \mathrm{C}$ for $30 \mathrm{~s}, 55^{\circ} \mathrm{C}$ for $30 \mathrm{~s}$, and then $72{ }^{\circ} \mathrm{C}$ for $1 \mathrm{~min}$. Then the resulting DNA product was subjected for the second round of nested PCR for 30 cycles: $94^{\circ} \mathrm{C}$ for $30 \mathrm{~s}, 55^{\circ} \mathrm{C}$ for $30 \mathrm{~s}$, and then $72{ }^{\circ} \mathrm{C}$ for $1 \mathrm{~min}$. Primers for GAPDH forward $\left(5^{\prime}\right.$-TGCMTCCTGCACCACCAACT- $\left.3^{\prime}\right)$ and reverse

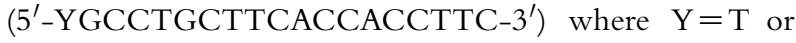
$\mathrm{C}$ and $\mathrm{M}=\mathrm{A}$ or $\mathrm{C}$ were used as control. Primers for the following genes, with sequences, were used: ER $\alpha$ forward primer (5'-AATTCTGACAATCGACGCAG-3') and reverse (5'-GTGCTTCAACATTCTCCCTCCTC$3^{\prime}$ ); ER $\alpha$ nested forward primer (5'-GAGAAAGGAAACATGATCATGGA- $\left.3^{\prime}\right)$ and nested reverse $\left(5^{\prime}\right.$-TTCATCATGCCCACTTGGTAAC- $3^{\prime}$ ); ER $\beta$ forward primer $\left(5^{\prime}\right.$-ACGAAGTAGGAATGGTCAAGTGT- $\left.3^{\prime}\right)$ and reverse $\left(5^{\prime}\right.$-ATGCCAAAATTTCCAGAATC- $\left.3^{\prime}\right) ; \quad$ ER $\beta$ nested forward (5'-AAAGCCAAGAGAACCAGTGGGCAC-3') and nested reverse $\left(5^{\prime}\right.$-GCCAATCATGTGCACCAGTTCCTT- $3^{\prime}$ ). As a negative control, PCR was also performed on the RNA samples without reverse transcription and confirmed that the bands detected in the reverse transcribed samples were not amplified from contaminating genomic DNA (data not shown).

\section{Western-blot hybridization}

Ovaries were homogenized in sample buffer (2\% SDS, $10 \%$ glycerol, $25 \mathrm{mM}$ Tris $\mathrm{pH}$ 6.8, $0 \cdot 00005 \%$ bromophenol blue, and $0.025 \%$ mercaptoethanol) plus mini complete protease inhibitor (Sigma). PND 1, 4, and 7 ovaries were 
homogenized in $10 \mu \mathrm{l}$ sample buffer/ovary. Adult ovaries were homogenized in $200 \mu \mathrm{l}$ /ovary. For each sample, $20 \mu \mathrm{l}$ solubilized protein extract (equivalent to approximately two ovaries) was mixed with $1 / 10$ volume of mercaptoethanol, heated to $95{ }^{\circ} \mathrm{C}$ for $3 \mathrm{~min}$, separated on $10 \%$ SDSpolyacrylamide gels and electroblotted onto Immobilon-P membranes (Millipore). The blots were incubated with a blocking solution containing 5\% nonfat milk powder in PBST (PBS/0.05\% Tween 20) overnight at $4{ }^{\circ} \mathrm{C}$ and incubated with primary antibodies in blocking solution for $1 \mathrm{~h}$ at room temperature. The primary antibodies used were ER $\alpha$ (MC20) at 1:500 (Santa Cruz Biotechnology) and ER $\beta$ (311) at 1:500 (Affinity Bioreagents). Following three washes in blocking solution, membranes were incubated with HRPconjugated secondary $\operatorname{IgG}(1: 25000)$ in blocking solution at room temperature for $1 \mathrm{~h}$, washed in PBST thrice, and signal visualized using the Supersignal kit (Pierce) on films. Blots were reprobed for GAPDH as a loading control.

\section{Results}

Er $\alpha$ and $\operatorname{Er} \beta m R N A$ s and protein are expressed in neonatal ovaries

We have previously shown that neonatal $\mathrm{E}_{2}$ treatment disrupts normal oocyte development by inhibiting cyst breakdown and primordial follicle formation (Chen et al. 2007). Previous research has validated the expression of ERs in ovaries of adult mice, with $\operatorname{Er} \alpha$ primarily in theca cells and $\operatorname{Er} \beta$ in granulosa cells (Jefferson et al. 2000). To determine when Er $\alpha$ and $E r \beta$ were expressed in developing ovaries, we used RT-PCR and western blotting. Both $E r \alpha$ and $\operatorname{Er} \beta$ mRNAs were detected in ovaries at PND 1, 4, 7, and 42 (Fig. 1A). ER $\alpha$ protein was detected by western blotting in ovaries at PND 1, 4, 7, and 92 (Fig. 1B). In PND 92 ovaries, the full-length $66 \mathrm{kDa}$ protein was detected while a slightly smaller protein was detected at PND 4, PND 7, and very weakly at PND 1. Several smaller isoforms of $\mathrm{ER} \alpha$ have been observed by others in tissue culture cells that lack part of the N-terminal of the protein (Heldring et al. 2007). ER $\beta$ protein was also detected by western blotting in ovaries at PND 1, 4, 7, and 92 (Fig. 1C). At all ages examined, proteins at two molecular masses were detected, one at about $50 \mathrm{kDa}$ and the other at about $30 \mathrm{kDa}$. As for $\mathrm{ER} \alpha$, several splice variants of ER $\beta$ have been observed in other tissues (Heldring et al. 2007).

To determine what cell types express ER $\alpha$ and ER $\beta$ protein in developing neonatal gonads, whole-mount immunocytochemistry was used at PND 1, 4, and 7. These time points were chosen at the span time of cyst breakdown. ER $\alpha$ was detected starting at PND 1 in somatic cells (data not shown). At PND 4 and 7, ER $\alpha$ was expressed more strongly in the granulosa cells as they surrounded the oocytes and formed primordial follicles (Fig. 2A-C). ER $\alpha$ was also expressed weakly in the cytoplasm of the oocytes. ER $\beta$ protein was detected at $18.5 \mathrm{dpc}$ and PND 1 in the nuclei
A
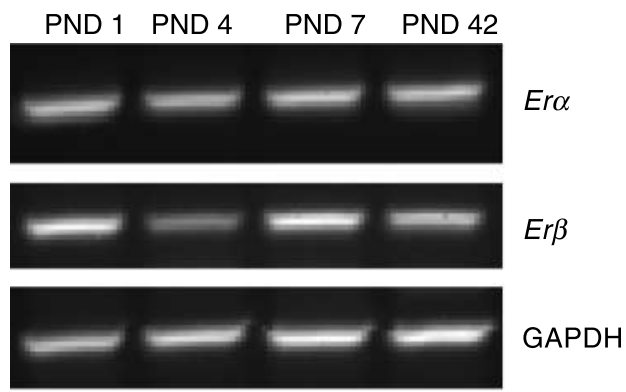

B

$\begin{array}{llll}\text { PND } 1 & \text { PND } 4 & \text { PND } 7 & \text { PND } 92\end{array}$
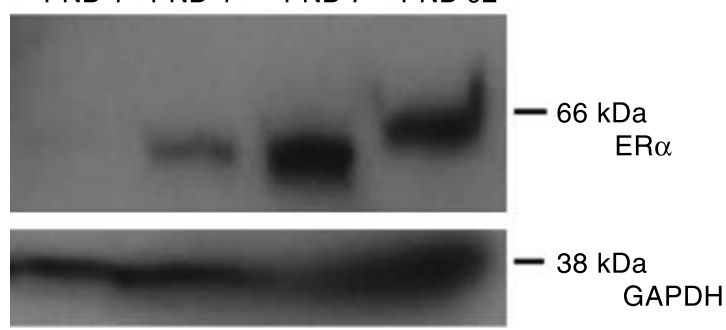

C

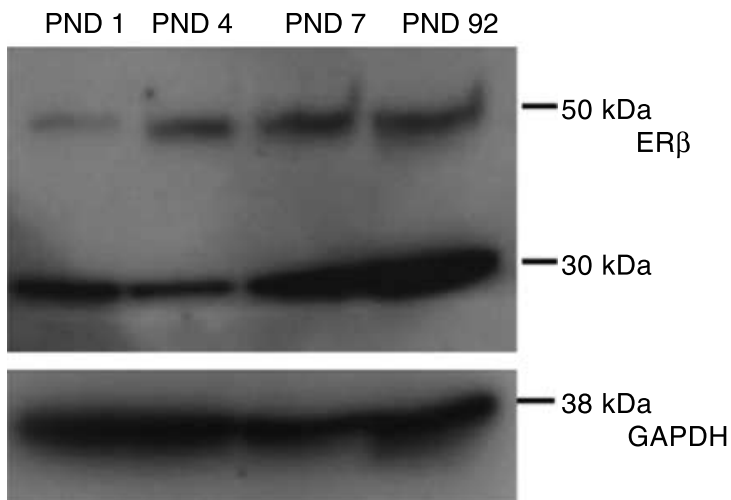

Figure 1 Estrogen receptor mRNA and protein expression in neonatal mouse ovaries. (A) mRNA was obtained from PND 1, 4, 7, and 42 ovaries and RT-PCR analysis was performed. Primers specific for GAPDH were used as a loading control. Er $\alpha$ and Er $\beta$ mRNAs were detected in neonatal as well as adult ovaries.

(B) Western-blotting analysis of ER $\alpha$. Mouse tissue extracts from PND 1, 4, 7, and 92 ovaries were probed with an ER $\alpha$ antibody. (C) Western-blotting analysis of ER $\beta$. Mouse tissue extracts from PND 1, 4, 7, and 92 ovaries were probed with an ER $\beta$ antibody. Blots were reprobed with GAPDH (38 kDa) as a loading control.

of a subset of oocytes but not at PND 4 or 7 (Fig. 2D-F). Thus, both ERs are present during cyst breakdown and primordial assembly.

\section{Selective ER agonists disrupt oocyte development in vitro}

We utilized ER-specific agonists to determine the involvement of each ER in neonatal oocyte development. Previously, it was shown that the effects of genistein on the ovary were mediated through ER $\beta$ (Jefferson et al. 2002). We expected 

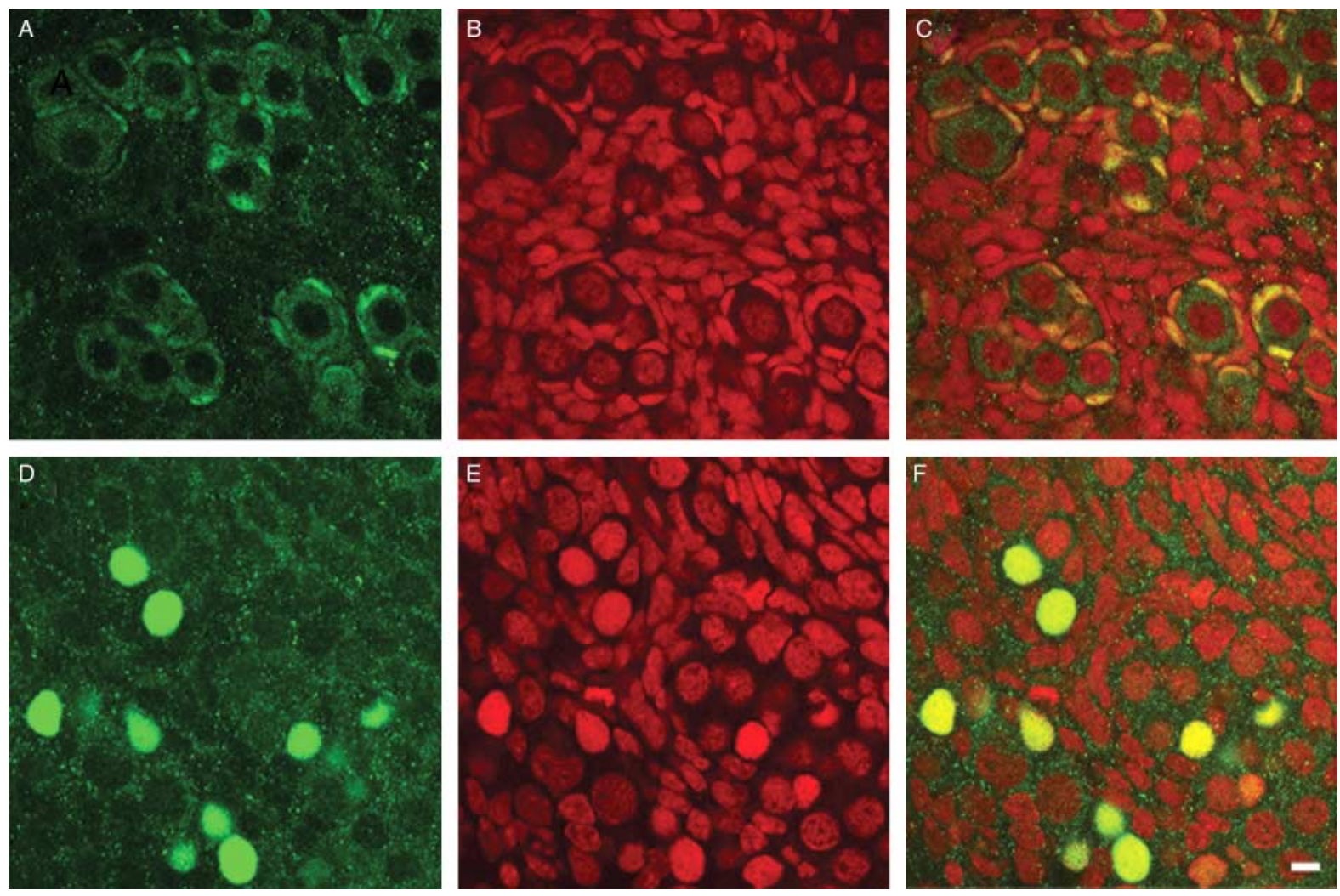

Figure 2 Expression of estrogen receptor proteins in whole-neonatal mouse ovaries. (A-C) Confocal section of a PND 7 mouse ovary labeled with an ER $\alpha$ antibody (A), propidium iodide (B), and overlay (C). (D-F) Confocal section of a PND 1 mouse ovary labeled with an $E R \beta$ antibody (D), propidium iodide (E), and overlay (F). Estrogen receptor antibodies (green) and propidium iodide to visualize nuclei (red). Scale bar $=10 \mu \mathrm{m}$. Full colour version of this figure available via http://dx.doi.org/10.1677/JOE-09-0109.

that the effects of $E_{2}$ on the ovary would also be mediated through ER $\beta$. DPN is an ER $\beta$-specific agonist, displaying 70 -fold higher binding affinity for ER $\beta$ than ER $\alpha$ (Meyers et al. 2001). DPN is 170 times more potent as a transcriptional activator through ER $\beta$ than ER $\alpha$. A dose-response curve was determined for DPN by examining the ability of DPN to stimulate gene expression from a promoter with an estrogen response element (ERE) and a $50 \%$ response using $10^{-9} \mathrm{M}$ was obtained with $\operatorname{ER} \beta$ (Harrington et al. 2003). To test for the involvement of ER $\beta$ in the regulation of cyst breakdown, ovaries were treated for 7 days starting at PND 1 with $10^{-8} \mathrm{M}$ DPN. The ovaries were analyzed for cyst breakdown and primordial follicle formation by determining the number of single oocytes relative to the number of oocytes in cysts. During this phase of ovarian development, cysts break apart and oocytes become enclosed by granulosa cells, forming primordial follicles. Although cyst breakdown and primordial follicle formation may be distinct events, currently we have no way to separate the two processes because they occur concurrently. Therefore, the percent of single oocytes is a measure for both these processes. DPN-treated ovaries had fewer single oocytes compared with controls (only 58\% compared with almost 90\%, Fig. 3A). Large cysts were still present in the agonist-treated ovaries but not in control ovaries after 7 days in culture (Fig. 3D and E).

During normal cyst breakdown, approximately two-thirds of the oocytes die. Previously, we showed that in vivo genistein treatment inhibited this death (Jefferson et al. 2006). However, $\mathrm{E}_{2}$ treatment in vivo or in ovary organ culture did not affect oocyte death (Chen et al. 2007). Here, oocyte number was also analyzed, and no significant difference was found between the control and DPN-treated ovaries (Fig. 3B). We also examined the follicle development. Normally, in the neonate, some primordial follicles are activated and begin to develop immediately. This first group of developing follicles is sometimes referred to as the first wave of developing follicles. We assessed follicle activation and development, and found that DPN did not affect primordial follicle activation or subsequent development (Fig. 3C).

The effect of PPT, an ER $\alpha$-selective agonist (Kraichely et al. 2000, Stauffer et al. 2000), was also tested. PPT displays 410-fold higher binding affinity for ER $\alpha$ than ER $\beta$. Similar to $E_{2}, P P T$ is a potent agonist acting through $E R \alpha$ in transactivation assays performed in human endometrial cancer (HEC) cells. A 50\% transactivation response was obtained with $10^{-9} \mathrm{M}$ PPT and an ERE containing 

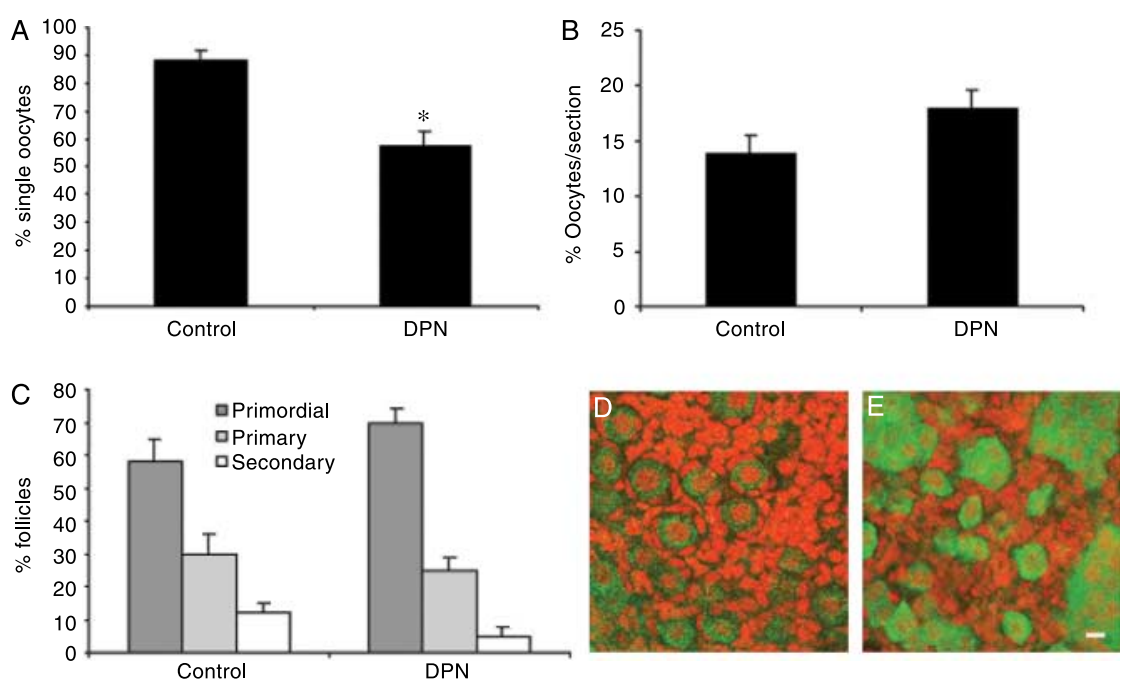

Figure 3 The ER $\beta$-specific agonist, DPN, inhibits cyst breakdown and primordial follicle assembly in organ culture. Percent single oocytes (A), number of oocytes per confocal section (B), and percent primordial, primary, and secondary follicles relative to the total number of follicles (C) in newborn ovaries after 7 days of culture in control ovaries and ovaries treated with $10^{-8}$ M DPN. Data are presented as the mean \pm S.E.M. *Indicates a significant difference between control and treated ovaries (ANOVA, $P<0 \cdot 05) . n=3-5$ ovaries per group. Confocal section of a control ovary (D) and an ovary cultured in $10^{-8} \mathrm{M} \mathrm{DPN}$ (E) grown in organ culture for 7 days labeled with STAT3 antibody to visualize oocytes (green) and propidium iodide to visualize nuclei (red). Scale bar $=10 \mu \mathrm{m}$. Full colour version of this figure available via http:// dx.doi.org/10.1677/JOE-09-0109.

promoter using ER $\alpha$ (Harrington et al. 2003). PPT is completely inactive in transactivation assays through ER $\beta$ even at very high concentrations. To test the effects of PPT, ovaries were collected from cluster of differentiation-1 mice on PND1 and cultured for 7 days. Ovaries were treated daily with $10^{-8} \mathrm{M}$ PPT. At the end of culture, ovaries were analyzed for cyst breakdown, oocyte survival, and follicle development by confocal microscopy following wholemount immunocytochemistry. Unexpectedly, after 7 days in culture, control ovaries had nearly $90 \%$ single oocytes, while the PPT-treated ovaries had significantly fewer single oocytes (68\%, Fig. 4A), showing that PPT inhibited cyst breakdown. Representative confocal images in Fig. 4D and E illustrate the effects of PPT on cyst breakdown. Although there was a slight increase in oocyte number in the PPT-treated ovaries (Fig. 4B), the difference was not significant. Follicle activation and development were not affected by PPT (Fig. 4C). Since DPN is an ER $\beta$-specific agonist and PPT is an ER $\alpha$-specific agonist, and both PPT and DPN inhibit cyst breakdown, we conclude that $E_{2}$ can signal through either $E R \alpha$ or $\operatorname{ER} \beta$ to inhibit oocyte cyst breakdown and primordial follicle assembly in the neonatal mouse ovary.

\section{ER antagonists can block the effects of estrogen}

ICI 182,780 is an estrogen antagonist that can bind to both $\operatorname{ER} \alpha$ and ER $\beta$ with very high affinity and is able to completely antagonize the effects of estrogen through both receptors (Wakeling et al. 1991). ICI 182,780 displays no agonist activity on estrogen target tissues. We used ICI 182,780 to block $E_{2}$ signaling through $E R \alpha$ and $E R \beta$ in developing mouse ovaries. Ovaries were collected from cluster of differentiation-1 mice on PND 1 and cultured for 7 days. Ovaries were treated daily with DMSO as control, with $10^{-7} \mathrm{M} \mathrm{E}_{2}$ alone, with $10^{-7} \mathrm{M} \mathrm{E}_{2}$ and $10^{-6} \mathrm{M}$ ICI 182,780, or with $10^{-7} \mathrm{M} \mathrm{E}_{2}$ and $10^{-5} \mathrm{M}$ ICI 182,780. At the end of culture, ovaries were stained and analyzed for cyst breakdown.

As expected, $E_{2}$ alone inhibited cyst breakdown, causing large cysts to persist and appearance of significantly fewer single oocytes (only 54\% compared with $79 \%$ in control, Fig. 5A). ICI 182,780 alone had no effect on cyst breakdown, because single oocyte remained the same as the control (Fig. 5A). When $\mathrm{E}_{2}$ and ICI 182,780 were added to the ovary in combination, inhibition of $\mathrm{E}_{2}$ on cyst breakdown was blocked by ICI 182,780 in a dosage-dependent manner (Fig. 5A). When ICI 182,780 was present at tenfold in the concentration of $\mathrm{E}_{2}$, the percent of single oocytes increased slightly to $62 \%$ and was further improved to $69 \%$ when ICI 182,780 was present at 100 -fold. Thus, blocking ER $\alpha$ and $\operatorname{ER} \beta$ resulted in inhibition of $E_{2}$ action on cyst breakdown.

ER-specific antagonists were used to further assess the role of each receptor in the ovary. First, to specifically inhibit ER $\alpha$, methyl-piperidino-pyrazole (MPP) was used as an ER $\alpha$-selective antagonist (Sun et al. 2002). MPP has a 200fold higher binding affinity for $\operatorname{ER} \alpha$ over $\operatorname{ER} \beta$, but does not 

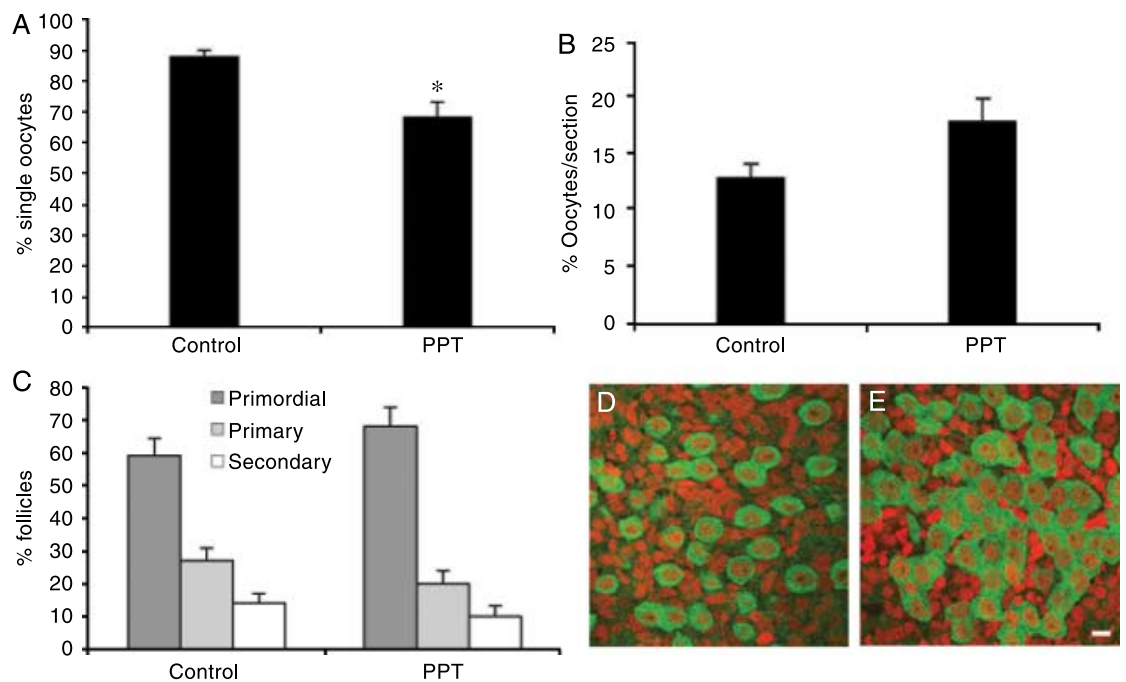

Figure 4 The ER $\alpha$-specific agonist, PPT, inhibits cyst breakdown and primordial follicle assembly in organ culture. Percent single oocytes (A), number of oocytes per confocal section (B), and percent primordial, primary, and secondary follicles (C) in newborn ovaries after 7 days of culture in control ovaries and ovaries treated with $10^{-8} \mathrm{M}$ PPT. Data are presented as the mean \pm s.E.M. * Indicates a significant difference between control and treated ovaries (ANOVA, $P<0 \cdot 05) . n=6$ ovaries per group. Confocal section of a control ovary (D) and an ovary cultured in $10^{-8} \mathrm{M}$ PPT (E) grown in organ culture for 7 days labeled with STAT3 antibody to visualize oocytes (green) and propidium iodide to visualize nuclei (red). Scale bar $=10 \mu \mathrm{m}$. Full colour version of this figure available via http://dx.doi.org/10.1677/JOE-09-0109.

activate transcription of reporter constructs in HEC cells through either receptor. In cotransfection experiments, MPP antagonizes the action of $\mathrm{E}_{2}$ through $\mathrm{ER} \alpha$ but not ER $\beta$. PND 1 ovaries from cluster of differentiation- 1 mice were cultured for 7 days. Ovaries were treated daily with $10^{-7} \mathrm{M} \mathrm{E}_{2}$ alone, or $10^{-7} \mathrm{M} \mathrm{E}_{2}$ and $10^{-6} \mathrm{M} \mathrm{MPP}$ or $10^{-7} \mathrm{M} \mathrm{E}_{2}$ and $10^{-5} \mathrm{M} \mathrm{MPP}$. At the end of culture, ovaries were analyzed for cyst breakdown.

Consistent with our previous results, $\mathrm{E}_{2}$ alone inhibited cyst breakdown, as shown by persistence of large cysts and fewer single oocytes (only $38 \%$ compared with $87 \%$ in the control, Fig. 5B). When MPP was added, no significant effect was observed when present at a tenfold higher concentration than $\mathrm{E}_{2}$ (Fig. 5B). However, when MPP concentration was 100 -fold more than $E_{2}$, the inhibition of $E_{2}$ on cyst breakdown was blocked resulting in fewer large cysts, similar to control ovaries, and an increase in single oocyte percent to $76 \%$ (Fig. $5 \mathrm{~B}$ ). The ER $\alpha$-selective antagonist, MMP, was able to block the effect of $E_{2}$ on cyst breakdown in the neonatal ovary.

$\mathrm{R}, \mathrm{R}$-tetrahydrochrysene ( $\mathrm{R}, \mathrm{R}-\mathrm{THC}$ ) is an ER $\beta$-selective antagonist, which retains partial ER $\alpha$-binding affinity (Sun et al. 1999). R, R-THC is able to bind to both $\mathrm{ER} \alpha$ and $\mathrm{ER} \beta$, but has a sevenfold higher binding affinity for $\operatorname{ER} \beta$ (Sun et al. 1999). In transactivation assays, R,R-THC was able to fully suppress $\mathrm{E}_{2}$ stimulation of ER $\beta$ but not $\mathrm{ER} \alpha$ (Sun et al. 1999). In addition to its ability to antagonize $\mathrm{ER} \beta, \mathrm{R}, \mathrm{R}-\mathrm{THC}$ was able to act as an agonist through ER $\alpha$, but had no effect through ER $\beta$ (Sun et al. 1999). Similar to our previous experiments, we found that $10^{-7} \mathrm{M} \mathrm{E}_{2}$ inhibited cyst breakdown and primordial follicle formation, causing large cysts to persist in the cultured ovaries, and single oocytes to drop to $44 \%$ compared with $81 \%$ in the control ovaries (Fig. 5C). Since R,R-THC can act as an agonist through $\mathrm{ER} \alpha$, it is not surprising that we found R,R-THC alone inhibited cyst breakdown similar to estrogen, although to a lesser extent, with $62 \%$ single oocytes (THC) compared with $44 \%\left(E_{2}\right)$ (Fig. 5C). When ovaries were treated with both $E_{2}$ and R,R-THC, the effect of $E_{2}$ on cyst breakdown was partially suppressed. More large cysts were observed in the ovaries and single oocyte percentage was higher $(71 \%$ and $63 \%$ single oocytes) though not completely restored to control levels (80\% single oocytes; Fig. 5C). Thus, R,RTHC acted as an antagonist of the effects of $E_{2}$ on cyst breakdown through ER $\beta$.

\section{Estrogen can signal through the membrane to regulate oocyte cyst breakdown}

We wondered whether nonclassical estrogen signaling could be involved in neonatal oocyte development. In order to test whether an mER could be involved in the cyst breakdown process, we utilized BSA conjugated to $\mathrm{E}_{2}\left(\mathrm{E}_{2}-\mathrm{BSA}\right)$. The size of $\mathrm{BSA}$ renders $\mathrm{E}_{2}$ unable to pass through the cell membrane and bind to ERs located in the nucleus. BSA conjugated to $\mathrm{E}_{2}$ has been widely used to test for $\mathrm{E}_{2}$ signaling through membrane receptors (Berthois et al. 1986). Ovaries were collected from cluster of differentiation-1 mice on PND 1 and 
cultured for 7 days. Ovaries were treated daily with DMSO as a control, $10^{-6} \mathrm{MBSA}$, or with $10^{-6} \mathrm{ME}_{2}-\mathrm{BSA}$. At the end of culture, ovaries were harvested and analyzed for cyst breakdown, oocyte survival, and follicle development by wholemount immunocytochemistry and confocal microscopy.
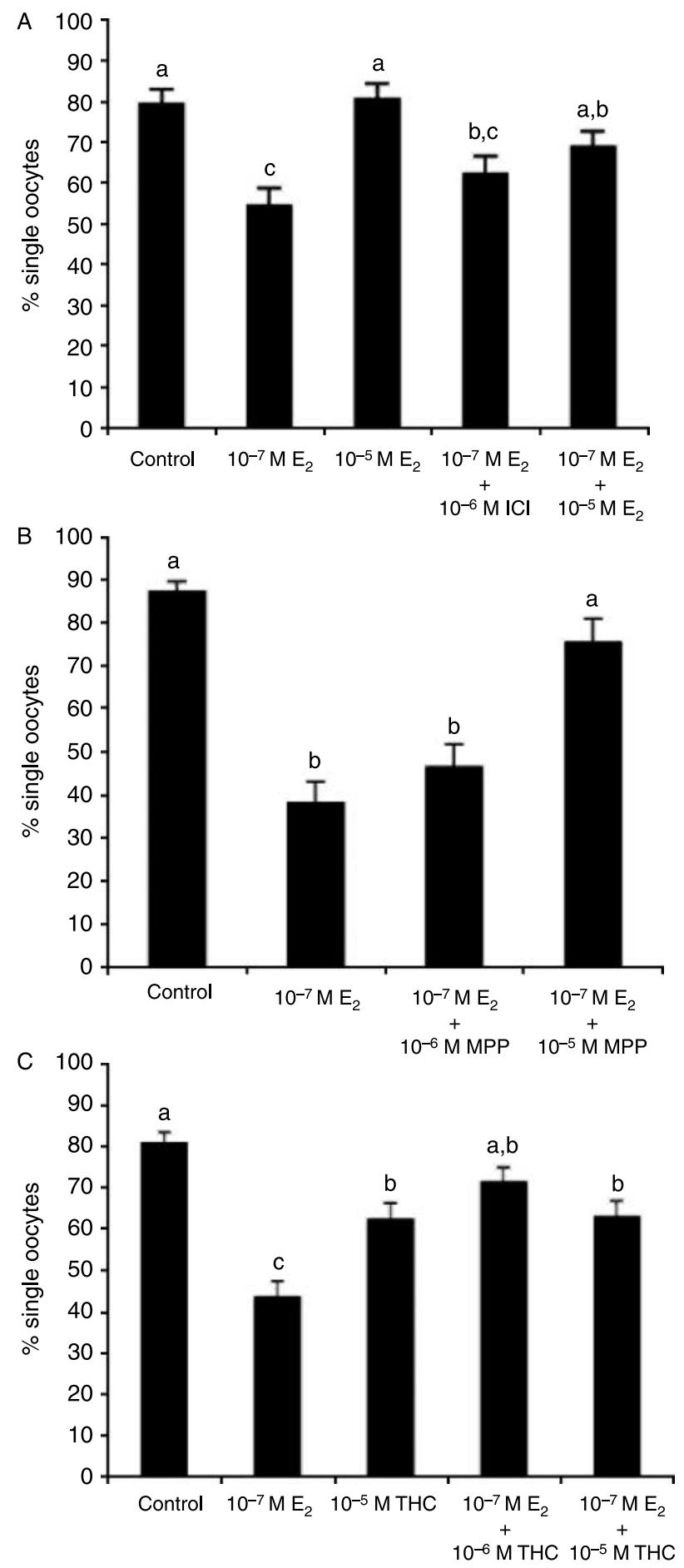

As illustrated in Fig. 6, BSA alone had no significant effect on cyst breakdown or primordial follicle assembly, because the percent of single oocytes remained the same (84\% compared with $89 \%$ in control ovaries, Fig. 6A). $\mathrm{E}_{2}-\mathrm{BSA}$ significantly inhibited cyst breakdown and primordial follicle assembly to an even greater extent than $\mathrm{E}_{2}$ alone. Treated ovaries exhibited large cysts (Fig. 6F) and decreased numbers of single oocytes (only 39\% single oocytes compared with $89 \%$ in the control, Fig. 6A), while in control or BSA-treated ovaries most oocytes were single (Fig. 6D and E). The number of primordial and primary follicles relative to the total number of follicles was similar in control, BSA-treated, and $\mathrm{E}_{2}$-BSA-treated ovaries but there were fewer secondary follicles in the $\mathrm{E}_{2}-\mathrm{BSA}$-treated ovaries (Fig. 6C). Neither BSA alone nor $\mathrm{E}_{2}-\mathrm{BSA}$ had any significant effect on oocyte number (Fig. 6B). This suggests the involvement of a $\mathrm{mER}$ in the process of cyst breakdown and primordial follicle assembly.

\section{Discussion}

The establishment of the primordial follicle pool is important for female fertility. In turn, cyst breakdown is a prerequisite for primordial follicle assembly. In our previous research, we have shown that neonatal treatment with genistein, $\mathrm{E}_{2}$, or progesterone inhibits cyst breakdown and primordial follicle formation (Chen et al. 2007). Our working model is that maternal estrogen inhibits cyst breakdown in the developing fetus before birth. After birth, estrogen levels in the neonate drop dramatically, allowing cysts to break down and individual oocytes to become enclosed in primordial follicles. Here, we investigated the mechanism of estrogen signaling using receptor-specific agonists and antagonists. According to our data, estrogen can signal through ER $\alpha$ or ER $\beta$. Both $\mathrm{ER} \alpha$ and $\mathrm{ER} \beta$ are expressed in neonatal ovaries supporting the idea that they play an important role in cyst breakdown.

We found ER $\alpha$ in granulosa cells at PND1, 4, and 7 and ER $\beta$ in oocytes at $18.5 \mathrm{dpc}$ and PND1. Our results differ from a previous study where $\mathrm{ER} \alpha$ was found in interstitial cells at PND 1, 5, 12, 19, and 26, and ER $\beta$ was found in

Figure 5 Estrogen receptor antagonists blocked the effects of $E_{2}$ on cyst breakdown in organ culture. (A) Percent single oocytes in newborn ovaries after 7 days of culture in control ovaries and ovaries treated with $10^{-7} \mathrm{ME}_{2}, 10^{-5} \mathrm{M} \mathrm{ICl} 182,780,10^{-7} \mathrm{M} \mathrm{E}_{2}$

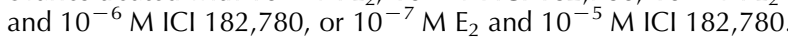
$n=6-8$ ovaries per group. (B) Percent single oocytes in newborn ovaries after 7 days of culture in control ovaries and ovaries treated with $10^{-7} \mathrm{ME}_{2}, 10^{-7} \mathrm{ME}_{2}$ and $10^{-6} \mathrm{MMPP}$, or $10^{-7} \mathrm{M} \mathrm{E}_{2}$ and $10^{-5}$ M MPP. $n=4-5$ ovaries per group. (C) Percent single oocytes in newborn ovaries after 7 days of culture in control ovaries and ovaries treated with $10^{-7} \mathrm{ME}_{2}, 10^{-5} \mathrm{M} \mathrm{R}, \mathrm{R}-\mathrm{THC}, 10^{-7} \mathrm{ME}_{2}$ and $10^{-6} \mathrm{M} \mathrm{R}, \mathrm{R}-\mathrm{THC}$, or $10^{-7} \mathrm{M} \mathrm{E}_{2}$ and $10^{-5} \mathrm{M} \mathrm{R}, \mathrm{R}-\mathrm{THC} . n=6-9$ ovaries per group. Data are presented as the mean \pm S.E.M. Different letters indicate a significant difference between groups (one-way ANOVA, $P<0 \cdot 05)$. 
A
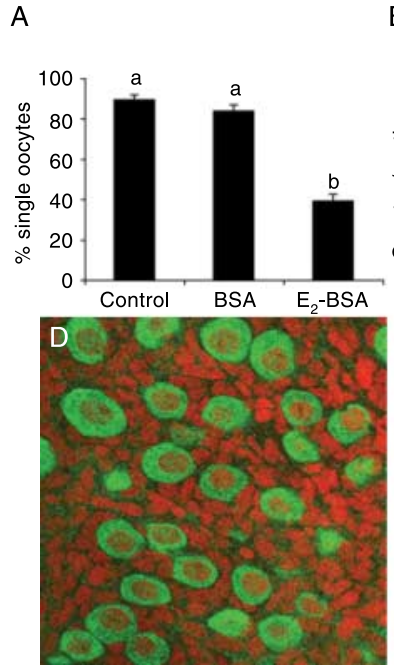

B
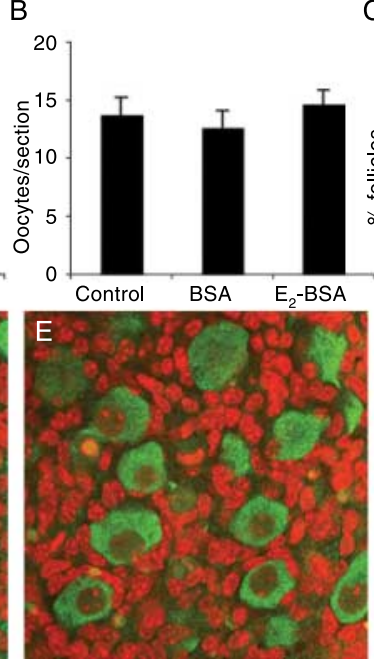

C
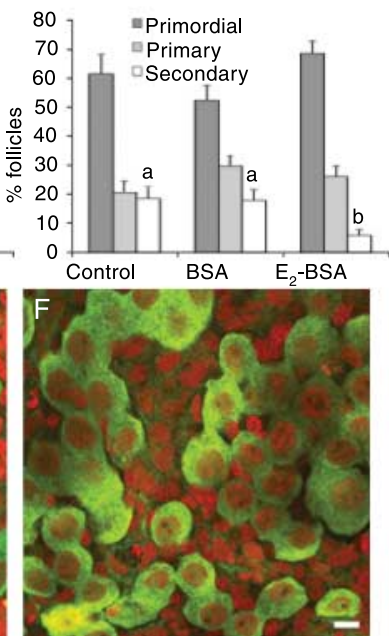

Figure $6 \mathrm{E}_{2}-\mathrm{BSA}$ inhibits cyst breakdown and follicle development in organ culture. Percent single oocytes (A), number of oocytes per confocal section (B), and percent primordial, primary, and secondary follicles $(\mathrm{C})$ in newborn ovaries after 7 days of culture in control ovaries and ovaries treated with $10^{-6} \mathrm{M}$ BSA or $10^{-6} \mathrm{ME}_{2}-$ BSA. Data are presented as the mean \pm s.E.M. Different letters indicate a significant difference between groups (ANOVA, $P<0 \cdot 05$ ). $n=5-10$ ovaries per group. Confocal section of a control ovary (D), an ovary cultured in $10^{-6} \mathrm{M} \mathrm{BSA}$ (E), and an ovary cultured in $10^{-6} \mathrm{M} \mathrm{E}_{2}-\mathrm{BSA}(\mathrm{F})$ grown in organ culture for 7 days labeled with STAT3 antibody to visualize oocytes (green) and propidium iodide to visualize nuclei (red). Scale bar $=10 \mu \mathrm{m}$. Full colour version of this figure available via http://dx.doi.org/10.1677/JOE09-0109.

granulosa cells at PND 5, 12, 19, and 26 (Jefferson et al. 2000). There are several isoforms of each ER and it is possible that each study is detecting different isoforms. Supporting this idea, each study used different antibodies generated against different epitopes of the receptors. For ER $\beta$, our studies here found the protein only in some oocytes and only at $18.5 \mathrm{dpc}$ and PND 1 and may not have been detected previously.

Previous research has implicated ER $\beta$ in the process of cyst breakdown. If mice are exposed neonatally to genistein, an estrogenic compound from soy plants, MOFs are induced in the adult ovary. However, genistein failed to induce MOFs in $\operatorname{Er} \beta$ knockout mice (Jefferson et al. 2002). In the studies described here, using ER-specific agonists, we found that estrogen signaling through both $\operatorname{ER} \alpha$ and $\operatorname{ER} \beta$ can affect ovarian differentiation. This discrepancy can be explained by the preferential binding affinity of genistein. Genistein binds to $\operatorname{ER} \beta$ much more strongly than $\mathrm{ER} \alpha$ and is a more potent activator of $E R \beta$ (Morito et al. 2001).

Analysis of ER knockout mice has shed some light on the roles of ER $\alpha$ and ER $\beta$ in the ovary. Single- and doubleknockout mice appear to have normal early oocyte development. Although some normal primordial follicles and growing follicles can be seen in the adult ovary, they have problems in later follicle development or ovulation (Lubahn et al. 1993, Krege et al. 1998, Couse et al. 1999). No defects in neonatal ovary development have been described in mutants of either nuclear ER. However, cyst breakdown and primordial follicle assembly have not been characterized in the knockout mice.

Using BSA-conjugated $\mathrm{E}_{2}$, we also detected the involvement of a $\mathrm{mER}$ in the process of cyst breakdown. It is possible that there could be a small amount of free $E_{2}$ in the $E_{2}-B S A$ preparation, but it is unlikely that it is present in a high enough concentration to affect our results. Several cell lines have been shown to possess high-affinity $\mathrm{E}_{2}$-binding sites on their plasma membranes (Berthois et al. 1986). The identity of the $\mathrm{mER}$ is still under debate (reviewed in Warner \& Gustafsson 2006). It has been suggested that ER $\alpha$ can translocate to the cell membrane and function to activate the nongenomic pathway (Razandi et al. 2003). On the other hand, there is also evidence that GPR30, a G-proteincoupled receptor, is the novel functional mER (Revankar et al. 2005, Filardo et al. 2007). However, GPR30 mutants have recently been generated and are fertile with no reproductive abnormalities detected (Otto et al. 2009).

Oocyte death accompanies cyst breakdown. Only onethird of all the oocytes in cysts will be enclosed in primordial follicles with the others undergoing apoptosis. Although these two processes are closely related, the exact relationship between them is unclear. Recent evidence has suggested that oocyte death is required for cyst breakdown because mutants without Bax protein, an apoptosis regulator, have more oocytes and cyst breakdown is delayed (Greenfeld et al. 2007). In addition, in vivo genistein treatment of neonates not only 
inhibits cyst breakdown, but also the results in fewer oocytes dying than untreated neonates again linking the processes of cyst breakdown and oocyte death (Jefferson et al. 2006). However, we have recently found that neonatal estrogen treatment, in vitro or in vivo, or genistein treatment in vitro had no effect on oocyte death. The difference of effects on cell death depending on the mode of delivery may reflect differences in the mechanism of action of genistein depending on how the ovary receives it. However, premature oocyte death that can be triggered by prenatal in vitro culture is rescued by the addition of estrogen (Chen et al. 2007). It may be that cell death is triggered when the mice are born and are no longer exposed to maternal estrogen, and the addition of estrogen after birth is not able to reverse the cell death unlike its action with cyst breakdown. Here, similar to $\mathrm{E}_{2}$, neither ER-specific agonist had an effect on oocyte number. This illustrates the underlying complexity of the estrogen-signaling pathway. The gene encoding the BCL2 protein, important in the apoptosis pathway, possesses an ERE in its promoter region (Klinge 2001). Therefore, the BCL2 protein could be the potential link between the estrogen pathway and the apoptosis pathway. One simple model is that estrogen signaling only regulates the apoptosis pathway before birth. Supporting this hypothesis, as mentioned above, estrogen can rescue the premature oocyte loss in the prenatal culture. In fetal ovaries, estrogens inhibit apoptosis and maintain the integrity of cysts. The dramatic drop of estrogen levels at birth triggers the oocyte death process and induces cyst breakdown. After birth, the link between estrogen-signaling pathway and apoptosis is turned off and estrogen can no longer affect the cell death process. This could be achieved by substituting ER co-activators with co-repressors or by changing the phosphorylation status of apoptosis target proteins so that they become inactive.

Several possible downstream targets of estrogen signaling have been suggested. Activin was originally isolated based on its ability to stimulate the synthesis and secretion of FSH (de Kretser \& Robertson 1989). Recently, it has been shown that activin promotes the establishment of the primordial follicle pool because neonatal activin treatment significantly increases the number of primordial follicles (Bristol-Gould et al. 2006). Activin expression and downstream signaling are suppressed in neonatal ovaries exposed to estrogen (Kipp et al. 2007). It is possible that estrogen inhibits cyst breakdown by suppressing activin activity before birth.

Both the ER $\alpha$ - and ER $\beta$-specific agonists were able to inhibit cyst breakdown, suggesting that estrogen could signal through either receptor to affect cyst breakdown. We expected that when ovaries were exposed to a receptorspecific antagonist in combination with $\mathrm{E}_{2}, \mathrm{E}_{2}$ would still have an effect on cyst breakdown by functioning through the other receptor. Instead, we observed a complete block of $E_{2}$ on cyst breakdown inhibition by the $\operatorname{ER} \alpha$ antagonist and a partial block by the ER $\beta$ antagonist. One possibility is that $\mathrm{ER}$ is functioning as a heterodimer of $\mathrm{ER} \alpha$ and $\mathrm{ER} \beta$. There is evidence that $\operatorname{ER} \alpha$ and $\operatorname{ER} \beta$ can act as heterodimers in some tissues (Cowley et al. 1997, Pace et al. 1997), but it is unclear whether the ERs are functioning as heterodimers in the neonatal ovary. However, this possibility is unlikely as $\operatorname{ER} \alpha$ and $\operatorname{ER} \beta$ are expressed in different cell types.

More work needs to be done to fully understand the mechanisms behind cyst breakdown and oocyte death. Elucidation of how estrogen normally regulates these processes and how neonatal exposure to excess environmental estrogenic compounds disrupts them will give us insight into female infertility and possible treatments.

\section{Declaration of interest}

The authors declare that there is no conflict of interest that could be perceived as prejudicing the impartiality of the research reported.

\section{Funding}

This research was supported by National Science Foundation grant IOB0613895 (to M E P)

\section{Acknowledgements}

We thank Brian Calvi, Grant Gephardt, and Nicole Patterson for their helpful comments on the manuscript.

\section{References}

Bendel-Stenzel M, Anderson R, Heasman J \& Wylie C 1998 The origin and migration of primordial germ cells in the mouse. Seminars in Cell and Developmental Biology 9 393-400.

Berthois Y, Pourreau-Schneider N, Gandilhon P, Mittre H, Tubiana N \& Martin PM 1986 Estradiol membrane binding sites on human breast cancer cell lines. Use of a fluorescent estradiol conjugate to demonstrate plasma membrane binding systems. Journal of Steroid Biochemistry 25 963-972.

Bristol-Gould SK, Kreeger PK, Selkirk CG, Kilen SM, Cook RW, Kipp JL, Shea LD, Mayo KE \& Woodruff TK 2006 Postnatal regulation of germ cells by activin: the establishment of the initial follicle pool. Developmental Biology 298 132-148.

Chen Y, Jefferson WN, Newbold RR, Padilla-Banks E \& Pepling ME 2007 Estradiol, progesterone, and genistein inhibit oocyte nest breakdown and primordial follicle assembly in the neonatal mouse ovary in vitro and in vivo. Endocrinology 148 3580-3590.

Couse JF, Hewitt SC, Bunch DO, Sar M, Walker VR, Davis BJ \& Korach KS 1999 Postnatal sex reversal of the ovaries in mice lacking estrogen receptors alpha and beta. Science 286 2328-2331.

Cowley SM, Hoare S, Mosselman S \& Parker MG 1997 Estrogen receptors alpha and beta form heterodimers on DNA. Journal of Biological Chemistry 272 19858-19862.

Dupont S, Krust A, Gansmuller A, Dierich A, Chambon P \& Mark M 2000 Effect of single and compound knockouts of estrogen receptors alpha (ERalpha) and beta (ERbeta) on mouse reproductive phenotypes. Development 127 4277-4291.

Enmark E \& Gustafsson JA 1999 Oestrogen receptors - an overview. Journal of Internal Medicine 246 133-138.

Filardo E, Quinn J, Pang Y, Graeber C, Shaw S, Dong J \& Thomas P 2007 Activation of the novel estrogen receptor $\mathrm{G}$ protein-coupled receptor 30 (GPR30) at the plasma membrane. Endocrinology 148 3236-3245.

Greenfeld CR, Pepling ME, Babus JK, Furth PA \& Flaws JA 2007 BAX regulates follicular endowment in mice. Reproduction 133 865-876. 
Harrington WR, Sheng S, Barnett DH, Petz LN, Katzenellenbogen JA \& Katzenellenbogen BS 2003 Activities of estrogen receptor alpha- and betaselective ligands at diverse estrogen responsive gene sites mediating transactivation or transrepression. Molecular and Cellular Endocrinology 206 $13-22$.

Heldring N, Pike A, Andersson S, Matthews J, Cheng G, Hartman J, Tujague M, Strom A, Treuter E, Warner M et al. 2007 Estrogen receptors: how do they signal and what are their targets. Physiological Reviews $\mathbf{8 7}$ 905-931.

Jefferson WN, Couse JF, Banks EP, Korach KS \& Newbold RR 2000 Expression of estrogen receptor beta is developmentally regulated in reproductive tissues of male and female mice. Biology of Reproduction $\mathbf{6 2}$ 310-317.

Jefferson WN, Couse JF, Padilla-Banks E, Korach KS \& Newbold RR 2002 Neonatal exposure to genistein induces estrogen receptor (ER)alpha expression and multioocyte follicles in the maturing mouse ovary: evidence for ERbeta-mediated and nonestrogenic actions. Biology of Reproduction 67 1285-1296.

Jefferson W, Newbold R, Padilla-Banks E \& Pepling M 2006 Neonatal genistein treatment alters ovarian differentiation in the mouse: inhibition of oocyte nest breakdown and increased oocyte survival. Biology of Reproduction 74 161-168.

Kipp JL, Kilen SM, Bristol-Gould S, Woodruff TK \& Mayo KE 2007 Neonatal exposure to estrogens suppresses activin expression and signaling in the mouse ovary. Endocrinology 148 1968-1976.

Klinge CM 2001 Estrogen receptor interaction with estrogen response elements. Nucleic Acids Research 29 2905-2919.

Kraichely DM, Sun J, Katzenellenbogen JA \& Katzenellenbogen BS 2000 Conformational changes and coactivator recruitment by novel ligands for estrogen receptor-alpha and estrogen receptor-beta: correlations with biological character and distinct differences among SRC coactivator family members. Endocrinology 141 3534-3545.

Krege JH, Hodgin JB, Couse JF, Enmark E, Warner M, Mahler JF, Sar M, Korach KS, Gustafsson JA \& Smithies O 1998 Generation and reproductive phenotypes of mice lacking estrogen receptor beta. PNAS 95 $15677-15682$.

de Kretser DM \& Robertson DM 1989 The isolation and physiology of inhibin and related proteins. Biology of Reproduction 40 33-47.

Lubahn DB, Moyer JS, Golding TS, Couse JF, Korach KS \& Smithies O 1993 Alteration of reproductive function but not prenatal sexual development after insertional disruption of the mouse estrogen receptor gene. PNAS 90 11162-11166.

Meyers MJ, Sun J, Carlson KE, Marriner GA, Katzenellenbogen BS \& Katzenellenbogen JA 2001 Estrogen receptor-beta potency-selective ligands: structure-activity relationship studies of diarylpropionitriles and their acetylene and polar analogues. Journal of Medicinal Chemistry $\mathbf{4 4}$ 4230-4251.

Morito K, Hirose T, Kinjo J, Hirakawa T, Okawa M, Nohara T, Ogawa S, Inoue S, Muramatsu M \& Masamune Y 2001 Interaction of phytoestrogens with estrogen receptors alpha and beta. Biological and Pharmaceutical Bulletin 24 351-356.

Murphy K, Carvajal L, Medico L \& Pepling M 2005 Expression of Stat3 in germ cells of developing and adult mouse ovaries and testes. Gene Expression Patterns 5 475-482.
Nielsen M, Bjornsdottir S, Hoyer PE \& Byskov AG 2000 Ontogeny of oestrogen receptor alpha in gonads and sex ducts of fetal and newborn mice. Journal of Reproduction and Fertility 118 195-204.

Otto C, Fuchs I, Kauselmann G, Kern H, Zevnik B, Andreasen P, Schwarz G, Altmann H, Klewer M, Schoor M et al. 2009 GPR30 does not mediate estrogenic responses in reproductive organs in mice. Biology of Reproduction 80 34-41.

Pace P, Taylor J, Suntharalingam S, Coombes RC \& Ali S 1997 Human estrogen receptor beta binds DNA in a manner similar to and dimerizes with estrogen receptor alpha. Journal of Biological Chemistry 272 25832-25838.

Pedram A, Razandi M \& Levin ER 2006 Nature of functional estrogen receptors at the plasma membrane. Molecular Endocrinology 20 1996-2009.

Pepling ME 2006 From primordial germ cell to primordial follicle: mammalian female germ cell development. Genesis 44 622-632.

Pepling ME \& Spradling AC 1998 Female mouse germ cells form synchronously dividing cysts. Development 125 3323-3328.

Pepling ME \& Spradling AC 2001 Mouse ovarian germ cell cysts undergo programmed breakdown to form primordial follicles. Developmental Biology 234 339-351.

Pettersson K \& Gustafsson JA 2001 Role of estrogen receptor beta in estrogen action. Annual Review of Physiology 63 165-192.

Razandi M, Alton G, Pedram A, Ghonshani S, Webb P \& Levin ER 2003 Identification of a structural determinant necessary for the localization and function of estrogen receptor alpha at the plasma membrane. Molecular and Cellular Biology 23 1633-1646.

Revankar CM, Cimino DF, Sklar LA, Arterburn JB \& Prossnitz ER 2005 A transmembrane intracellular estrogen receptor mediates rapid cell signaling. Science 307 1625-1630.

Stauffer SR, Coletta CJ, Tedesco R, Nishiguchi G, Carlson K, Sun J, Katzenellenbogen BS \& Katzenellenbogen JA 2000 Pyrazole ligands: structure-affinity/activity relationships and estrogen receptor-alpha-selective agonists. Journal of Medicinal Chemistry 43 4934-4947.

Sun J, Meyers MJ, Fink BE, Rajendran R, Katzenellenbogen JA \& Katzenellenbogen BS 1999 Novel ligands that function as selective estrogens or antiestrogens for estrogen receptor-alpha or estrogen receptorbeta. Endocrinology 140 800-804.

Sun J, Huang YR, Harrington WR, Sheng S, Katzenellenbogen JA \& Katzenellenbogen BS 2002 Antagonists selective for estrogen receptor alpha. Endocrinology 143 941-947.

Wakeling AE, Dukes M \& Bowler J 1991 A potent specific pure antiestrogen with clinical potential. Cancer Research 51 3867-3873.

Warner M \& Gustafsson JA 2006 Nongenomic effects of estrogen: why all the uncertainty? Steroids 71 91-95.

Received in final form 20 May 2009

Accepted 8 June 2009

Made available online as an Accepted Preprint

8 June 2009 